\title{
Balloon pulmonary angioplasty in chronic thromboembolic pulmonary hypertension
}

\author{
Irene Lang ${ }^{1}$, Bernhard C. Meyer ${ }^{2}$, Takeshi Ogo ${ }^{3}$, Hiromi Matsubara ${ }^{4}$, \\ Marcin Kurzyna ${ }^{5}$, Hossein-Ardeschir Ghofrani ${ }^{6,7}$, Eckhard Mayer ${ }^{8}$ and \\ Philippe Brenot ${ }^{9}$
}

\begin{abstract}
Affiliations: 'Dept of Internal Medicine II, Division of Cardiology, Medical University of Vienna, Vienna, Austria. ${ }^{2}$ Dept of Diagnostic and Interventional Radiology, Hannover Medical School, Hannover, Germany. ${ }^{3}$ Division of Pulmonary Circulation, Dept of Advanced Medicine for Pulmonary Hypertension, National Cerebral and Cardiovascular Center, Suita, Japan. ${ }^{4}$ Dept of Clinical Science, National Hospital Organization, Okayama Medical Centre, Okayama, Japan. ${ }^{5}$ Dept of Pulmonary Circulation and Thromboembolic Diseases, Medical Centre of Postgraduate Education, European Health Centre Otwock, Otwock, Poland. ${ }^{6}$ Universities of Giessen and Marburg Lung Center, Giessen, Germany, Member of the German Center for Lung Research (DZL). ${ }^{7}$ Dept of Medicine, Imperial College London, London, UK. ${ }^{8}$ Kerckhoff Heart and Lung Center, Bad Nauheim, Germany. ${ }^{9}$ Hôpital Marie Lannelongue, Le Plessis-Robinson, France.
\end{abstract}

Correspondence: Irene Lang, Medical University of Vienna, Internal Medicine II, Division of Cardiology, Währinger, Gürtel, 18-20, 1090 Vienna, Austria. E-mail: irene.langdameduniwien.ac.at

@ERSpublications

Balloon pulmonary angioplasty is an emerging percutaneous vascular intervention for non-operable CTEPH http://ow.ly/tIN3309hys3

Cite this article as: Lang I, Meyer BC, Ogo $\mathrm{T}$, et al. Balloon pulmonary angioplasty in chronic thromboembolic pulmonary hypertension. Eur Respir Rev 2017; 26: 160119 [https://doi.org/10.1183/ 16000617.0119-2016].

ABSTRACT Chronic thromboembolic pulmonary hypertension (CTEPH) is thought to result from incomplete resolution of pulmonary thromboemboli that undergo organisation into fibrous tissue within pulmonary arterial branches, filling pulmonary arterial lumina with collagenous obstructions. The treatment of choice is pulmonary endarterectomy (PEA) in CTEPH centres, which has low post-operative mortality and good long-term survival. For patients ineligible for PEA or who have recurrent or persistent pulmonary hypertension after surgery, medical treatment with riociguat is beneficial. In addition, percutaneous balloon pulmonary angioplasty (BPA) is an emerging option, and promises haemodynamic and functional benefits for inoperable patients. In contrast to conventional angioplasty, BPA with undersized balloons over guide wires exclusively breaks intraluminal webs and bands, without dissecting medial vessel layers, and repeat sessions are generally required. Observational studies report that BPA improves haemodynamics, symptoms and functional capacity in patients with CTEPH, but controlled trials with long-term follow-up are needed. Complications include haemoptysis, wire injury, vessel dissection, vessel rupture, reperfusion pulmonary oedema, pulmonary parenchymal bleeding and haemorrhagic pleural effusions. This review summarises the available evidence for BPA, patient selection, recent technical refinements and periprocedural imaging, and discusses the potential future role of BPA in the management of CTEPH.

This article has been revised according to the correction published in the June 2017 issue of the European Respiratory Review. Received: Dec 092016 | Accepted after revision: Feb 222017

Conflict of interest: Disclosures can be found alongside this article at err.ersjournals.com

Provenance: Publication of this peer-reviewed article was sponsored by Bayer AG, Berlin, Germany (principal sponsor, European Respiratory Review issue 143).

Copyright OERS 2017. ERR articles are open access and distributed under the terms of the Creative Commons Attribution Non-Commercial Licence 4.0. 


\section{Introduction}

Chronic thromboembolic pulmonary hypertension (CTEPH), a rare, potentially life-threatening disease of the pulmonary vasculature, is a distinct entity (group 4) in the classification of pulmonary hypertension [1].

CTEPH is believed to develop when a pulmonary embolism does not resolve and transforms into fibrous tissue that occludes the pulmonary artery [2-6]. Dysfunction and remodelling of the pulmonary microvasculature similar to the arteriopathy of pulmonary arterial hypertension (PAH) are thought to contribute significantly to the pathology of CTEPH.

Patients with untreated CTEPH are at high risk of progressive pulmonary hypertension, right heart failure and death [7]. Early diagnosis and treatment by a multidisciplinary team are essential [8,9]. Pulmonary endarterectomy (PEA) is the gold-standard treatment. PEA is a potentially curative intervention, which in expert centres carries an in-hospital mortality rate $<5 \%$ and confers haemodynamic and functional improvement with good long-term survival $[10,11]$. However, $<60 \%$ of patients with CTEPH can undergo PEA, and pulmonary hypertension persists or recurs after the procedure in $17-31 \%$ of patients $[12,13]$.

For patients who are ineligible for surgery or who have persistent or recurrent pulmonary hypertension following PEA, targeted medical therapies developed for PAH can be given [1]. The soluble guanylate cyclase stimulator riociguat is currently the only medical therapy licensed for the treatment of CTEPH and has been shown to improve haemodynamics and exercise capacity (class I recommendation, level of evidence B) [1, 14]. Phosphodiesterase (PDE)-5 inhibitors, endothelin receptor antagonists (ERAs) and prostanoids are not approved for this indication, because of a lack of positive randomised study evidence (class IIb recommendation, level of evidence B) [1]. The results of a randomised trial of macitentan $10 \mathrm{mg} \cdot \mathrm{day}^{-1}$ compared with placebo are expected soon.

Percutaneous balloon pulmonary angioplasty (BPA) is an emerging option for patients with CTEPH who are not eligible for surgery or who have recurrent or persistent pulmonary hypertension following PEA. This review summarises the available evidence for BPA, recent technical refinements, patient selection and periprocedural imaging.

\section{History, evolution and evidence for BPA}

Published studies of BPA are discussed below and summarised in table 1 [9, 15-32, 43]. The first full report was published in 2001 by FeInstein et al. [15] in the USA, describing 18 patients with inaccessible or "nonsurgical" CTEPH. Reperfusion pulmonary oedema (RPO) occurred in 11 patients and 30-day mortality was 5.5\%. Follow-up (mean 36 months) reported improvements in mean pulmonary arterial pressure (mPAP), New York Heart Association (NYHA) functional class and 6-min walking distance (6MWD), and all vessels previously dilated were patent at angiographic reassessment.

Following FeINSTEIN et al.'s report, BPA was abandoned for some years, mainly because of high complication rates. However, more recent reports, mainly from Japan, have revived interest. SUGIMURA et al. [17] performed BPA in 12 patients with distal-type CTEPH stabilised for 1-3 months with prostanoids, sildenafil and/or bosentan. Pulmonary haemodynamics were improved, and survival was better than for historical controls. KАТАOKA et al. [16] performed BPA in 29 patients with inoperable CTEPH, most of whom had previously been treated with an ERA, PDE-5 inhibitor or prostanoid. Functional class, brain natriuretic peptide (BNP) levels and haemodynamics were improved at follow-up; medication was unchanged in most patients. Notably, haemodynamic effects took time to develop after BPA.

Shortly after these studies were published, ANDREASSEN et al. [18] reported results with BPA for segmental and subsegmental pulmonary arteries in 20 patients in Norway with inoperable disease or persistent pulmonary hypertension after PEA. NYHA functional class and haemodynamic values were significantly improved, but periprocedural mortality was $10 \%$ and RPO occurred in seven patients. After 51 months' follow-up, $85 \%$ of patients were still alive. Three further publications from European centres, one in 37 patients [9] and two others, each in nine patients [24, 25], described improvements in mPAP, exercise capacity and functional class after BPA, with low rates of complications.

Most studies of BPA to date have been conducted in patients with a baseline $\mathrm{mPAP}>30 \mathrm{mmHg}$, and predictors of treatment success have been identified as duration from symptom onset, baseline diastolic PAP and diastolic pressure gradient [33].

Several Japanese centres have described improvements in haemodynamics, symptoms and exercise capacity after BPA, with generally low rates of major complications and post-procedural mortality [19, 21, 22, 26, $27,29,30,32]$, with some follow-up over a year [21, 22, 30].

BPA has been described in nine patients who had undergone PEA but had gradually deteriorated after an initially favourable response [20]. Haemodynamics and functional class were improved at follow-up. Those 
TABLE 1 Published results with balloon pulmonary angioplasty (BPA) in the management of patients with chronic thromboembolic pulmonary hypertension (CTEPH)

\begin{tabular}{|c|c|c|c|c|c|c|c|c|c|c|}
\hline $\begin{array}{l}\text { First author, } \\
\text { year [ref.] }\end{array}$ & $\begin{array}{l}\text { Patients } \\
\text { (location) }\end{array}$ & Procedures & $\begin{array}{l}\text { CTEPH medical } \\
\text { therapy pre-BPA }\end{array}$ & $\begin{array}{c}\text { Mean } \\
\text { age years }\end{array}$ & $\begin{array}{l}\text { Reduction in } \\
\text { mPAP mmHg }\end{array}$ & FC improvement & $\begin{array}{c}\text { 6MWD } \\
\text { improvement }\end{array}$ & Complications & $\begin{array}{c}\text { Acute mortality } \\
\{<30 \text { days after BPA } \mid\end{array}$ & $\begin{array}{l}\text { Long-term } \\
\text { outcomes }\end{array}$ \\
\hline $\begin{array}{l}\text { FEINSTEIN, } \\
2001[15]\end{array}$ & 18 (USA) & $\begin{array}{c}47 \\
\text { catheterisations } \\
107 \text { dilations } \\
\text { Mean 2.6 } \\
\text { procedures per } \\
\text { patient }\end{array}$ & $N R$ & $52 \pm 12$ & $\begin{array}{c}43.0 \pm 12.1 \text { to } \\
33.7 \pm 10.2 \\
(p=0.007)\end{array}$ & $\begin{array}{c}\text { NYHA FC } 3.3 \text { to } 1.8 \\
(p<0.001)\end{array}$ & $\begin{array}{l}209 \text { to } 497 \text { yards } \\
(p<0.0001)\end{array}$ & $\begin{array}{c}\text { 11/18 RPO } \\
3 / 18 \mathrm{MV}\end{array}$ & $\begin{array}{c}1(5.6 \%) \\
\text { RPO + RHF, day } 7\end{array}$ & $\begin{array}{l}16 / 18(89 \%) \\
\text { alive at } \\
34.2 \text { months }\end{array}$ \\
\hline $\begin{array}{l}\text { Mızoguchl, } 2012 \\
\text { [43] }\end{array}$ & 68 (Japan) & $\begin{array}{c}255 \text { sessions; } \\
2-8 \text { sessions } \\
\text { per patient; } \\
\text { 1-14 vessels } \\
\text { dilated } \\
\text { per session }\end{array}$ & $\begin{array}{c}68 / 68 \\
\text { epoprostenol } \\
1-5 \mathrm{ng} \cdot \mathrm{kg}^{-1} \cdot \mathrm{min}^{-1} \\
\text { for } \sim 5 \text { days } \\
\text { pre-BPA }\end{array}$ & $62.2 \pm 11.9$ & $\begin{array}{c}45.4 \pm 9.6 \text { to } \\
24 \pm 6.4(p<0.01)\end{array}$ & $\begin{array}{c}\text { WHO FC } \\
3.0 \text { to } 2.0(p<0.01)\end{array}$ & $\begin{array}{l}296 \text { to } 368 \mathrm{~m} \\
(p<0.01)\end{array}$ & $\begin{array}{c}\text { 76/255 sessions } \\
\text { RPO } \\
\text { 4/68 patients MV }\end{array}$ & $1 \mathrm{RHF}$, day 28 & $\begin{array}{l}66 / 68(97 \%) \\
\text { alive at } 2.2 \\
\pm 1.4 \text { years }\end{array}$ \\
\hline $\begin{array}{l}\text { KATAOKA, } \\
2012[16]\end{array}$ & 29 (Japan) & $\begin{array}{l}51 \text { procedures } \\
\text { (mean } 1.8 \text { per } \\
\text { patient) } \\
\text { Mean } 3 \text { vessels } \\
\text { dilated per } \\
\text { session } \\
\text { Mean } 6.5 \text { vessels } \\
\text { per patient }\end{array}$ & $\begin{array}{l}\text { 14/29 bosentan } \\
2 / 29 \text { ambrisentan } \\
\text { 24/29 PDE-5i } \\
\text { 15/29 beraprost }\end{array}$ & $62.3 \pm 11.5$ & $\begin{array}{c}45.3 \pm 9.8 \text { to } \\
31.8 \pm 10(p<0.01)\end{array}$ & $\begin{array}{l}\text { At } 6 \text { months } \\
\text { NYHA FC } \\
(p<0.01)^{\#}\end{array}$ & NR & $\begin{array}{c}27 / 51 \text { procedures } \\
\text { RPO } \\
1 / 29 \text { patients MV }\end{array}$ & $\begin{array}{l}1 \text { wire perforation } \\
\text { of PA }\end{array}$ & NR \\
\hline $\begin{array}{l}\text { SugimURA, } \\
\quad 2012[17]\end{array}$ & $\begin{array}{c}12 \text { with } \\
\text { distal webs } \\
39 \text { controls } \\
\text { (Japan) }\end{array}$ & $\begin{array}{l}\text { Mean } 5 \\
\text { procedures } \\
14 \text { lesions }\end{array}$ & $\begin{array}{l}\text { 1-3 months } \\
\text { pre-BPA: } \\
\text { 7/12 epoprostenol } \\
5 / 12 \text { beraprost } \\
11 / 12 \text { sildenafil } \\
5 / 12 \text { bosentan }\end{array}$ & 58 & $\begin{array}{c}\text { Mean } \pm \text { SEM } \\
47.8 \pm 11.6 \text { to } \\
24.8 \pm 4.9(p<0.01)\end{array}$ & $\begin{array}{c}\text { WHO FC } \\
\text { II/III/IV 33/42/25\% } \\
\text { at baseline; } 100 \% \\
\text { FC II at follow-up }\end{array}$ & $\begin{array}{c}\text { Mean } \pm \text { SEM } \\
350 \pm 105 \mathrm{~m} \text { to } \\
441 \pm 76 \mathrm{~m} \\
(\mathrm{p}<0.05)\end{array}$ & $6 / 12$ haemoptysis & 0 & $\begin{array}{l}\text { All alive at } \\
\text { mean } \\
12 \text { months }\end{array}$ \\
\hline $\begin{array}{l}\text { ANDREASSEN, } \\
2013[18]\end{array}$ & $\begin{array}{c}20 \\
\text { (Norway) }\end{array}$ & $\begin{array}{c}73 \\
\text { catheterisations } \\
\text { Mean } 3.7 \\
\text { procedures and } \\
\text { 18.6 BPAs per } \\
\text { patient }\end{array}$ & $\begin{array}{c}\text { 2/20 sildenafil, } \\
\text { stopped before } \\
\text { BPA }\end{array}$ & $60 \pm 10$ & $\begin{array}{c}45 \pm 11 \text { to } 33 \pm 10 \\
(p<0.001)\end{array}$ & $\begin{array}{c}\text { NYHA FC } 3.0 \pm 0.5 \\
\text { to } 2.0 \pm 0.5 \\
(p<0.001)\end{array}$ & NR & $7 / 20 \mathrm{RPO}$ & $\begin{array}{c}1 \text { RVF, day } 1 \\
1 \text { acute } \mathrm{PE} \text {, day } 9\end{array}$ & $\begin{array}{c}17 / 20(85 \%) \\
\text { patients alive } \\
\text { at median } \\
51 \text { months }\end{array}$ \\
\hline $\begin{array}{l}\text { Fukul, } \\
\quad 2014 \text { [19] }\end{array}$ & 20 (Japan) & $\begin{array}{c}\text { Mean } 3.2 \pm 0.9 \\
\text { procedures per } \\
\text { patient }\end{array}$ & $\begin{array}{c}\text { 5/20 ERA } \\
13 / 20 \text { PCA } \\
4 / 20 \text { PDE-5i } \\
\text { 6/20 } \\
\text { combination } \\
\text { therapy }\end{array}$ & $67 \pm 9.0$ & $\begin{array}{c}39.4 \pm 7.6 \text { to } \\
27.3 \pm 8.5(p<0.001)\end{array}$ & $\begin{array}{c}\text { WHO FC } 2.8 \text { to } 2.0 \\
(p<0.001)\end{array}$ & $\begin{array}{c}361 \pm 104 \mathrm{~m} \text { to } \\
463 \pm 76 \mathrm{~m} \\
(p<0.001)\end{array}$ & No major events & 0 & $\begin{array}{l}\text { NR (1-year } \\
\text { retrospective } \\
\text { study) }\end{array}$ \\
\hline $\begin{array}{l}\text { SHIMURA, } \\
\quad 2015 \text { [20] }\end{array}$ & $\begin{array}{c}110, \\
\text { including } \\
9 \text { post-PEA } \\
\text { (Japan) }\end{array}$ & $\begin{array}{c}423 \\
44 \text { BPA sessions } \\
\text { in } 9 \text { post-PEA } \\
\text { patients }\end{array}$ & NR & $\begin{array}{l}55.1 \text { (post-PEA } \\
\text { patients) }\end{array}$ & 43 to $26(p<0.05)$ & $\begin{array}{c}\text { NYHA FC } \\
\text { I/II/III/IV } 0 / 3 / 5 / 1 \text { to } \\
7 / 2 / 0 / 0(p<0.05)\end{array}$ & NR & 1 RPO & 0 & $\begin{array}{l}9 / 9 \text { alive at } \\
\text { median } \\
1.97 \text { years } \\
\text { after BPA }\end{array}$ \\
\hline
\end{tabular}




\begin{tabular}{|c|c|c|c|c|c|c|c|c|c|c|}
\hline $\begin{array}{l}\text { First author, } \\
\text { year [ref.] }\end{array}$ & $\begin{array}{l}\text { Patients } \\
\text { (location) }\end{array}$ & Procedures & $\begin{array}{l}\text { CTEPH medical } \\
\text { therapy pre-BPA }\end{array}$ & $\begin{array}{l}\text { Mean } \\
\text { age years }\end{array}$ & $\begin{array}{l}\text { Reduction in } \\
\text { mPAP mmHg }\end{array}$ & FC improvement & $\begin{array}{c}\text { 6MWD } \\
\text { improvement }\end{array}$ & Complications & $\begin{array}{c}\text { Acute mortality } \\
\{<30 \text { days after BPA } \mid\end{array}$ & $\begin{array}{l}\text { Long-term } \\
\text { outcomes }\end{array}$ \\
\hline $\begin{array}{l}\text { INAMI, } \\
2014 \text { [21] }\end{array}$ & $\begin{array}{c}103 \\
\text { (Japan) }\end{array}$ & $\begin{array}{c}350 \text { procedures; } \\
145 \text { with PEPSI + } \\
\text { PWG }\end{array}$ & $\begin{array}{c}\text { Bosentan, } \\
\text { ambrisentan, } \\
\text { sildenafil, tadalafil } \\
\text { or beraprost }\end{array}$ & 65 & $\begin{array}{l}\text { In patients with } \\
\text { PEPSI + PWG, } \\
\text { from } 38 \text { to } \approx 24^{\pi}\end{array}$ & NR & $\begin{array}{l}\text { In patients with } \\
\text { PEPSI + PWG, } \\
\text { from } \approx 360 \text { to } \\
\approx 420 \mathrm{~m}^{\pi}\end{array}$ & $\begin{array}{c}0 \text { with PEPSI + } \\
\text { PWG }\end{array}$ & 0 with PEPSI + PWG & $\begin{array}{c}0 \text { at median } \\
6.4 \text { months } \\
\text { with BPA + } \\
\text { PEPSI + PWG }\end{array}$ \\
\hline $\begin{array}{l}\text { INAMI, } \\
2014 \text { [22] }\end{array}$ & 68 (Japan) & 213 sessions & $\begin{array}{c}\text { For BPA and PEA } \\
\text { patients combined } \\
\text { (n=107) } \\
\text { prostanoids } 60 \% \\
\text { PDE-5i } 66 \% \\
\text { ERAs } 55 \%\end{array}$ & 62 & 42.9 to 25.0 & $\begin{array}{c}\text { NYHA FC } \\
\text { improved }(p<0.05)\end{array}$ & $\begin{array}{l}349 \pm 130 \mathrm{~m} \text { to } \\
424 \pm 111 \mathrm{~m} \\
(p<0.0001)\end{array}$ & $\begin{array}{c}\text { RPO } 7.0 \% \\
\text { Haemosputum } \\
2.3 \% \\
\text { Haemoptysis 3.3\% } \\
\text { Dissection } 2.3 \% \\
\text { Perforation } 0.9 \%\end{array}$ & $1.47 \%$ & $\begin{array}{c}\text { Mortality } 1.5 \% \\
\text { at } 14.3 \\
\pm 10.4 \text { months }\end{array}$ \\
\hline $\begin{array}{l}\text { YanaGisaWA, } \\
2014 \text { [23] }\end{array}$ & $\begin{array}{c}\text { <65 years: } \\
39 \\
\geqslant 65 \text { years: } \\
31 \text { (Japan) }\end{array}$ & $\begin{array}{c}<65 \text { years: } \\
\text { mean } 4 \text { sessions } \\
\geqslant 65 \text { years: mean } 3 \\
\text { sessions }(p=0.054)\end{array}$ & $\begin{array}{l}\text { Bosentan, } \\
\text { ambrisentan, } \\
\text { sildenafil, tadalafil } \\
\text { or beraprost }\end{array}$ & $\begin{array}{l}<65 \text { years: } 54 \\
\geqslant 65 \text { years: } 70\end{array}$ & $\begin{array}{c}<65 \text { years: } \\
42 \text { to } 26.0 \\
\geqslant 65 \text { years: } \\
41 \text { to } 23.5(p=0.11)\end{array}$ & $\begin{array}{l}\text { Improved in both } \\
\text { groups }(p<0.05) \\
\text { More in age } \\
\geqslant 65 \text { years } \\
(p<0.0001)\end{array}$ & $\begin{array}{c}<65 \text { years: } \\
380 \text { to } 441 \mathrm{~m} \\
\geqslant 65 \text { years: } \\
310 \text { to } 409 \mathrm{~m} \\
\text { ( } \mathrm{p}=0.553)\end{array}$ & 1 wire perforation & & $\begin{array}{c}\text { At } 1 \text { year } \\
<65 \text { years: } 0 \% \\
\geqslant 65 \text { years: } \\
3.2 \%\end{array}$ \\
\hline KuRZYNA, 2015 [9] & 20 (Poland) & $\begin{array}{l}37 \text { procedures } \\
105 \text { vessels }\end{array}$ & $\begin{array}{l}82 \% \text { of patients, } \\
\text { mainly sildenafil }\end{array}$ & NR & $58 \pm 6$ to $41 \pm 9$ & $\begin{array}{l}\text { WHO FC III/IV 95\% } \\
\text { at baseline; } \\
35 \% \text { at follow-up }\end{array}$ & $\begin{array}{l}\text { Improved } \\
\text { exercise } \\
\text { tolerance }\end{array}$ & $2 \mathrm{RPO}$ & $10 \%$ (RPO) & NR \\
\hline $\begin{array}{l}\text { VelázQuez Martín, } \\
2015 \text { [24] }\end{array}$ & 7 (Spain) & $\begin{array}{l}22 \text { (mean } 3 \\
\text { procedures per } \\
\text { patient; each } \\
\text { procedure mean } \\
2.4 \text { segments, } \\
1.2 \text { lobes) }\end{array}$ & $\begin{array}{l}\text { ERA + sildenafil + } \\
\text { epoprostenol in } \\
\text { most patients }\end{array}$ & 61 & $\begin{array}{c}56 \pm 17 \text { to } 36 \pm 10 \\
(p<0.06)\end{array}$ & $\begin{array}{c}\text { NYHA FC } 3.8 \pm 0.2 \\
\text { to } 2.3 \pm 0.2 \\
(p<0.001)\end{array}$ & NR & $2 \mathrm{RPO}$ & 1 CVA day 7 & $N R$ \\
\hline Roık, 2016 [25] & 9 (Poland) & $\begin{array}{c}27 \text { sessions in } \\
9 \text { patients } \\
\text { Mean } 3 \text { per patient }\end{array}$ & 6/11 sildenafil & 76 & $\begin{array}{c}\text { Median (IQR) } \\
40(32-54) \text { to } \\
34.5(29-42) \\
(p=0.01)\end{array}$ & $\begin{array}{c}\text { NYHA FC } \\
\text { I/II/III/IV 0/0/6/3 to } \\
0 / 7 / 2 / 0 \text { ( } p=0.018)\end{array}$ & $\begin{array}{c}\text { Median (IQR) } \\
304(135-450) \\
\text { to } \\
304(205-530) \\
(p=0.03)\end{array}$ & $\begin{array}{c}2 \text { RPO } \\
1 \text { haemoptysis }\end{array}$ & 0 & NR \\
\hline АокІ, 2016 [26] & 25 (Japan) & $\begin{array}{l}113 \text { procedures } \\
\text { Mean } 4.7 \text { per } \\
\text { patient }\end{array}$ & $\begin{array}{c}\text { ERA } 4 \% \\
\text { PDE-5i } 71 \% \\
\text { Oral prostanoid } \\
21 \% \\
\text { Epoprostenol } 8 \% \\
\text { Riociguat } 12 \%\end{array}$ & $\begin{array}{l}\text { Median (IQR) } \\
70(60-74)\end{array}$ & $\begin{array}{c}\text { Median (IQR) } \\
37(28-45) \text { to } \\
23(19-27) \\
(p<0.01)\end{array}$ & $\begin{array}{c}\text { WHO FC } \\
\text { I/II/III/IV 0/50/46/ } \\
4 \% \text { at baseline; } \\
24 / 76 / 0 / 0 \% \text { at } \\
\text { follow-up ( } p=0.04 \text { ) }\end{array}$ & $\begin{array}{c}\text { Median (IQR) } \\
390 \\
(286-484) \mathrm{m} \text { to } \\
490(411-617) \mathrm{m} \\
(\mathrm{p}<0.01)\end{array}$ & $\begin{array}{c}\text { No severe } \\
\text { complications }\end{array}$ & 0 & NR \\
\hline
\end{tabular}




\begin{tabular}{|c|c|c|c|c|c|c|c|c|c|c|}
\hline $\begin{array}{l}\text { First author, } \\
\text { year [ref.] }\end{array}$ & $\begin{array}{l}\text { Patients } \\
\text { (location) }\end{array}$ & Procedures & $\begin{array}{l}\text { CTEPH medical } \\
\text { therapy pre-BPA }\end{array}$ & $\begin{array}{c}\text { Mean } \\
\text { age years }\end{array}$ & $\begin{array}{l}\text { Reduction in } \\
\text { mPAP mmHg }\end{array}$ & FC improvement & $\begin{array}{l}\text { 6MWD } \\
\text { improvement }\end{array}$ & Complications & $\begin{array}{c}\text { Acute mortality } \\
\{<30 \text { days after BPA })\end{array}$ & $\begin{array}{l}\text { Long-term } \\
\text { outcomes }\end{array}$ \\
\hline $\begin{array}{l}\text { KaWAKAMI, } 2016 \\
\text { [27] }\end{array}$ & 97 (Japan) & $\begin{array}{l}500 \text { procedures } \\
\text { Mean } 5.2 \text { per } \\
\text { patient } \\
\text { (1936 lesions) }\end{array}$ & $\begin{array}{c}\text { ERA } 47.4 \% \\
\text { PDE- } 5 \text { i } 36.1 \% \\
\text { Oral prostanoid } \\
50.5 \% \\
\text { i.v. prostanoid } \\
9.3 \%\end{array}$ & $61.7 \pm 12.3$ & $\begin{array}{c}45.1 \pm 10.8 \text { to } \\
23.3 \pm 6.4(p<0.01)\end{array}$ & $\begin{array}{c}\text { WHO FC } \\
\text { I/II/III/IV 0/0/70/ } \\
\text { 27\% at baseline; } \\
\text { 13/76/4/0\% at } \\
\text { follow-up }\end{array}$ & $\begin{array}{c}276.3 \pm 123.2 \mathrm{~m} \\
\text { to } 359.3 \pm 91.9 \mathrm{~m} \\
(p<0.01)\end{array}$ & $\begin{array}{c}\text { Haemoptysis } \\
(19.6 \%) \\
\text { Pulmonary injury } \\
(26.0 \%)\end{array}$ & $4 \%$ & NR \\
\hline KIMURA, 2016 [28] & 66 (Japan) & $\begin{array}{c}\text { Mean } 6.8 \text { sessions } \\
\text { per patient; mean } \\
\text { 13.1 vessels per } \\
\text { patient }\end{array}$ & $\begin{array}{c}\text { ERA 41\% } \\
\text { PDE-5i } 55 \% \\
\text { Prostanoid } 29 \% \\
\text { Riociguat } 11 \%\end{array}$ & $63.2 \pm 13.2$ & $\begin{array}{c}39.2 \pm 10.5 \text { to } \\
20.9 \pm 5.4(p<0.001)\end{array}$ & NR & NR & $\begin{array}{c}\text { Haemosputum } \\
\text { (6.1\%) } \\
\text { RPO requiring } \\
\text { NPPV (1.1\%) }\end{array}$ & 0 & $N R$ \\
\hline KoIKE, 2016 [29] & 8 (Japan) & $\begin{array}{c}16 \text { procedures } \\
\text { Mean } 2 \text { per patient }\end{array}$ & $\mathrm{NR}$ & $70.8 \pm 8.6$ & $\begin{array}{c}30.4 \pm 11.0 \text { to } \\
25.6 \pm 8.2(p=0.04)\end{array}$ & NR & $\begin{array}{c}332.3 \pm 59.6 \mathrm{~m} \text { to } \\
352.1 \pm \\
64.1 \mathrm{~m} \\
(p<0.0001)\end{array}$ & NR & 0 & NR \\
\hline OGo, 2016 [30] & 80 (Japan) & $\begin{array}{c}385 \text { sessions } \\
\text { Mean } 4.8 \text { per } \\
\text { patient (1155 } \\
\text { lesions) }\end{array}$ & $\begin{array}{c}\text { ERA } 23 \% \\
\text { PDE-5i } 25 \% \\
\text { Oral prostanoid } \\
42 \% \\
\text { i.v. prostanoid } 6 \% \\
\text { Riociguat } 6 \%\end{array}$ & $\begin{array}{l}\text { Median (IQR) } \\
68(58-76)\end{array}$ & $\begin{array}{c}42 \pm 11 \text { to } 25 \pm 6 \\
(p<0.01)\end{array}$ & $\begin{array}{c}\text { WHO FC } \\
3.0 \pm 0.4 \text { to } 1.8 \pm 0.4 \\
(p<0.01)\end{array}$ & $\begin{array}{c}372 \pm 124 \mathrm{~m} \text { to } \\
470 \pm 99 \mathrm{~m} \\
(p<0.01)\end{array}$ & $\begin{array}{c}\text { Wire perforation } \\
\text { (7.5\%) } \\
\text { RPO }(4.7 \%) \\
\text { Haemoptysis } \\
(4.7 \%)\end{array}$ & 0 & NR \\
\hline Tsugu, 2016 [31] & 26 (Japan) & $\begin{array}{l}\text { Mean } 6 \text { sessions } \\
\text { per patient }\end{array}$ & $\begin{array}{c}\text { ERA } 46 \% \\
\text { PDE-5i } 72 \% \\
\text { Prostanoid } 40 \%\end{array}$ & $63 \pm 16$ & $\begin{array}{c}38.3 \pm 8.4 \text { to } \\
18.0 \pm 4.2(p<0.01)\end{array}$ & $\begin{array}{c}\text { WHO FC } \\
2.9 \pm 0.6 \text { to } 1.2 \pm 0.4 \\
(p<0.01)\end{array}$ & $\begin{array}{c}326.8 \pm 83.7 \mathrm{~m} \text { to } \\
400.3 \pm 77.4 \mathrm{~m} \\
(p<0.01)\end{array}$ & NR & NR & NR \\
\hline $\begin{array}{l}\text { YamASAKI, } 2016 \\
\text { [32] }\end{array}$ & 29 (Japan) & $\begin{array}{c}\text { Mean } 2.7 \text { sessions } \\
\text { per patient }\end{array}$ & $\begin{array}{c}\text { ERA } 45 \% \\
\text { PDE- } 5 \mathrm{i} 50 \% \\
\text { Oral prostanoid } \\
40 \% \\
\text { Riociguat } 40 \%\end{array}$ & $61.9 \pm 10.6$ & $\begin{array}{c}42.6 \pm 11.0 \text { to } \\
30.0 \pm 6.6 \\
(p<0.0001)\end{array}$ & NR & $\begin{array}{l}391 \pm 75 \mathrm{~m} \text { to } \\
437 \pm 68 \mathrm{~m} \\
(p<0.0001)\end{array}$ & NR & 0 & NR \\
\hline
\end{tabular}

Data are presented as $n$ or mean \pm SD, unless otherwise stated. mPAP: mean pulmonary arterial pressure; FC: functional class; 6MWD: 6-min walking distance; NR: not reported; NYHA: New York Heart Association; RPO: reperfusion pulmonary oedema; MV: mechanical ventilation; RHF: right heart failure; PDE-5i: phosphodiesterase type-5 inhibitor; PA: pulmonary artery; WHO: World Health Organization; PE: pulmonary embolism; ERA: endothelin receptor antagonist; PCA: prostacyclin analogue; PEA: pulmonary endarterectomy; PEPSI: Pulmonary Edema Predictive Scoring Index; PWG: pressure-wire guidance; CVA: cerebrovascular accident; IQR: interquartile range; NPPV: non-invasive positive pressure ventilation. ${ }^{\#}$ : values not reported; " : estimated from graphs. 
authors and others recommend combined PEA and BPA for patients with both proximal and very distal lesions [20, 34]. One report from Japan described outcomes of CTEPH managed using drug therapy (including anticoagulants and pulmonary vasodilators), BPA or PEA [22]. Despite significantly worse haemodynamic parameters at baseline, patients managed with interventional therapies (PEA or BPA) had significantly superior survival at 5 years than those treated medically (98\% versus 64\%, respectively; $\mathrm{p}<0.0001)$. The efficacy and safety of BPA were similar in younger ( $<65$ years) and older ( $\geqslant 65$ years) patients [23]. Data comparing outcomes of PEA in operable patients with those of BPA in inoperable patients suggest that the efficacy and safety of the two procedures are similar in their target cohorts [35]. In addition to the improvements in haemodynamics and functional capacity, there is accumulating evidence that BPA leads to improvements in right ventricular function, including volumes, ejection fraction, peak systolic strain, myocardial remodelling and alleviation of dyssynchrony [31, 32, 36-38]. In addition, left ventricular function may be improved, although this has been studied less extensively [32, 36]. Improvements in mPAP and pulmonary vascular resistance (PVR) after BPA are associated with reductions in high-sensitivity troponin- $T$ levels, suggesting attenuation of myocardial injury [28]. In addition, BPA appears to improve respiratory function and oxygenation in patients with CTEPH [26, 39].

It is difficult to compare results between countries and regions because of differences in patient selection and procedures, and possible differences in vascular structure and function related to ethnicity or diet. To date, it is estimated that $\sim 600$ patients have been treated in Europe.

\section{Current BPA practice}

All patients with pulmonary hypertension, including CTEPH, should be evaluated and managed in a centre with specialist expertise and facilities [1], including a CTEPH team [40]. A referral centre should follow $\geqslant 50$ patients per month and receive at least two new referrals for PAH or CTEPH each month [1]. The recommendation to perform BPA in expert centres (as for PEA) is important, because BPA is a complex procedure that is not risk free. The first consideration in the evaluation of patients for BPA is the feasibility of PEA [1]. The European Society of Cardiology/European Respiratory Society guidelines [1] state that BPA may be considered for patients who are technically inoperable or who carry an unfavourable risk/benefit ratio for PEA (class IIb recommendation, level of evidence C). This recommendation covers a very diverse group and there are currently no data to identify those patients who might benefit the most from BPA. Patient groups in whom BPA could potentially be used include those with inoperable CTEPH due to distal distribution of vascular obstructions; those with an unfavourable risk/benefit ratio for PEA (for example, few lesions but severe haemodynamics, or extreme surgical risk because of comorbidities, etc.); patients with persistent/recurrent pulmonary hypertension after PEA; patients in need of rescue angioplasty after early failure of PEA [41]; patients with residual lesions after PEA; and patients with inoperable or persistent/recurrent CTEPH and an inadequate response to medical therapy. Some patients may have no distinct comorbidities that directly affect the surgical risk of PEA, but have limitations (e.g. general frailty, severe chronic obstructive pulmonary disease or inability to walk) such that the potential functional gain from surgery is very small ("low benefit" rather than "high risk"). BPA may be appropriate in these patients and is within the guideline recommendation. Conversely, BPA should not be offered to patients with large central clots or unilateral total occlusion.

BPA was made possible by technical advances and accumulating experience in the management of congenital and acquired pulmonary artery stenoses. The rationale is to open obstructed vessels or widen stenotic lesions using a catheter-based intervention rather than the invasive surgery of PEA. The intention is to improve haemodynamics and pulmonary perfusion, ultimately reducing right ventricular afterload and preventing right ventricular failure. In outline, the procedure consists of the identification of pulmonary artery lesions that can be treated; passage of a guide wire across the lesion or occlusion; and balloon dilatation of the target lesions to restore pulmonary blood flow. Staged procedures with repeat catheterisations and dilatations are needed to achieve optimal haemodynamic results. Long-term haemodynamic and clinical follow-up are essential.

Percutaneous vascular access for BPA is via the femoral or jugular vein, using long sheaths through which pre-shaped guiding catheters (e.g. multipurpose shape, right or left coronary Judkins or left Amplatz shape) are inserted. Anticoagulation throughout the procedure is based on heparin at a level below that required for coronary angioplasty (e.g. $2000 \mathrm{IU}$ heparin) given hourly. Supplemental oxygen is given to keep saturation levels above $95 \%$ during the procedure and to ease the breath hold for the patient. Patients are required to hold their breath for $\geqslant 20 \mathrm{~s}$ to allow the wire to enter lower lobe branches. A long 6-, 7- or 8-French sheath containing a pre-shaped 6-French guiding catheter is placed in the pulmonary trunk and guided to the right or left main pulmonary artery. Generally, the lobe with the worst perfusion identified by lung perfusion scintigraphy is treated first. A primary target for BPA (as for PEA) is the right lower 
lobe, because of its size and physiologically greater compartment of blood flow [42]. In patients with low mPAP (i.e. $<40 \mathrm{mmHg}$ ), more than one lobe may be treated in a single session $[16,17,43,44]$.

Pulmonary vascular lesions found in patients with CTEPH include fibrous webs, occlusions, tortuous lesions and pouches [45]. It is important to have information about peripheral branches distal to the lesion in order to perform BPA safely [42]. In severe cases, the primary goal is to reduce pressure by addressing simpler lesions first (i.e. web lesions or ring-like stenoses). The guide wire is passed carefully across the target lesion: proper guide wire placement must be proven before angioplasty can be performed (figure 1). Recent practice in Japan has employed pressure wires to measure the ratio of distal to proximal pressures across the target lesion: this information can be used to reduce the risk of RPO [21, 43]. In some cases, soft hydrophilic guide wires are used, e.g. for the management of occlusive pulmonary artery lesions. To begin the procedure, wires with tip loads $<1 \mathrm{~g}$ should be used. Balloons should be undersized (i.e. a low balloon/artery ratio) to reduce the risk of vessel injury and RPO: a 2-mm balloon is typically used for initial dilatation, followed by larger balloons according to lesion size and residual pressure. The balloon is inflated by hand until the fluoroscopic waist disappears or until the balloon is expanded at 5-8 atm. For that reason, compliant balloons are preferred. Repeat dilatations with bigger balloons are performed if there is $<50 \%$ increase in angiographic vessel size and an increase of pulmonary venous backflow is

a)

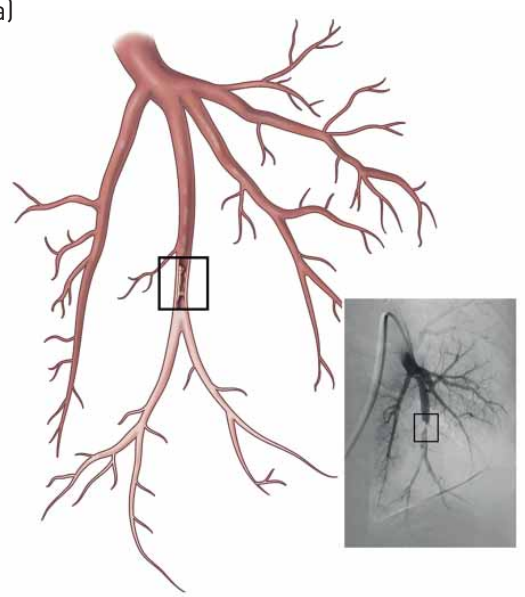

b)

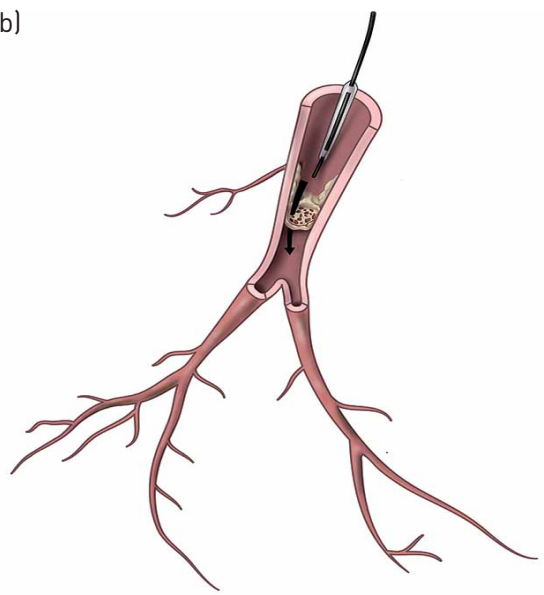

c)

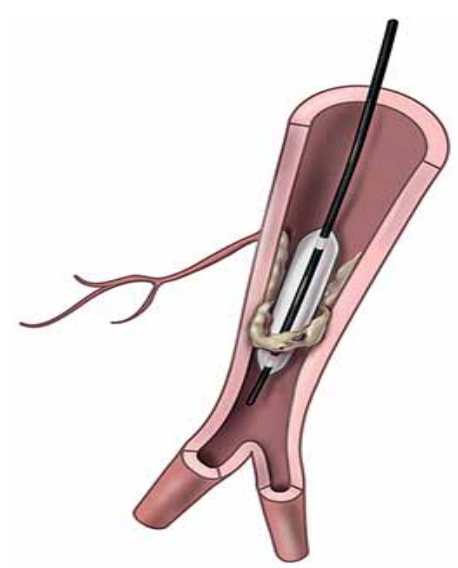

d)

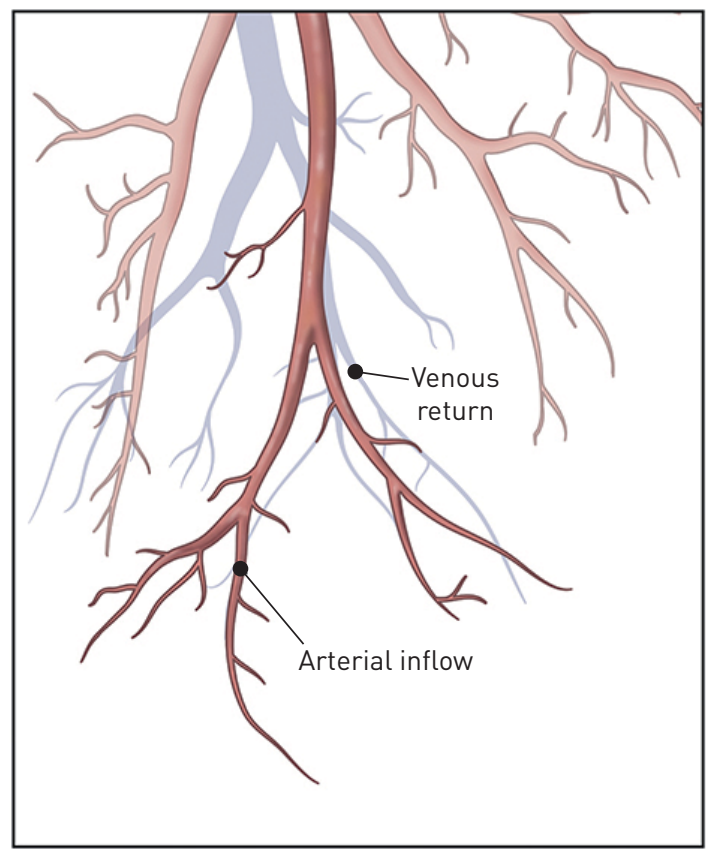

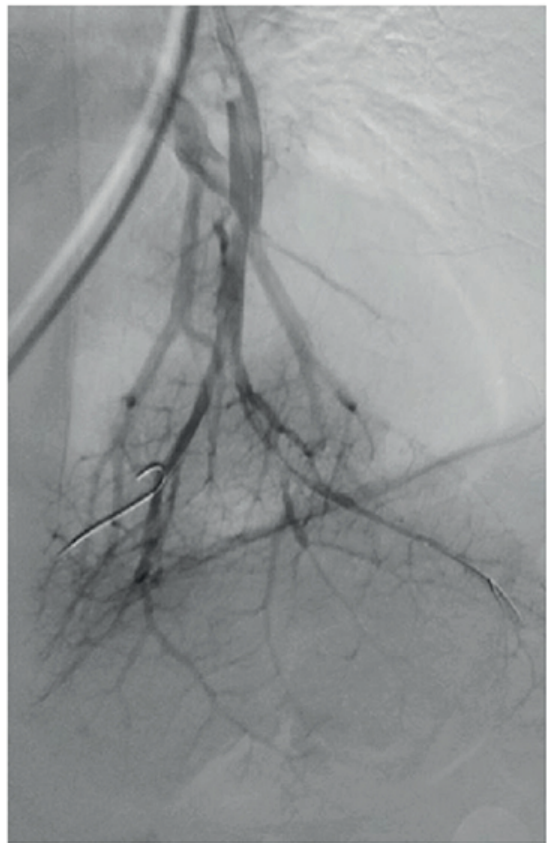

FIGURE 1 a) Pulmonary angiography, showing a stenosis in the subsegment of the 10th segmental artery (anterior view); b) the catheter is introduced into a web stenosis; c) the wire is introduced between the fibrotic material and the balloon is inflated, leading to rupture of the web. d) Angiography after balloon pulmonary angioplasty shows an improvement of blood flow with better perfusion of the parenchyma and quick venous return. In contrast to pulmonary endarterectomy, the fibrous material is not removed from the arteries, but is crushed against the vessel wall. 
documented. In case of chronic total occlusions, microcatheters and wires with higher tip loads are used, similar to conventional chronic total occlusion techniques. One retrograde chronic total occlusion procedure has been reported [46]. Complete haemodynamics, including PVR, are measured pre-BPA, and repeated before the next BPA.

Between three and 10 sessions of BPA are usually required for each patient, generally at intervals of $\geqslant 1$ week, to achieve the desired PAP reduction and treat all amenable lesions. The number of sessions required depends on the extent of disease, the location and configuration of the lesions and the skills of the operator. At each session, treatment is targeted to segmental and subsegmental pulmonary arteries of one pulmonary lobe. The need for repeated sessions is an important consideration when explaining the procedure, planning resources and evaluating potential hazards from repeated exposure to radiation and contrast media, including contrast-induced nephropathy. For the proper reporting of BPA, the numbers and types of lesions and the numbers of dilatations and sessions are monitored. Figure 2 shows pulmonary arterial imaging before and after BPA.

After BPA, many patients still show elevated pressure and resistance values [9]. Riociguat has effects on vascular and endothelial function that may be beneficial in CTEPH [47-52]. Consequently, hybrid therapy (medical treatment combined with BPA and PEA) may be a promising option [9]. This could include acute or chronic "bridging" treatment before BPA, to improve haemodynamics and potentially reduce the risk of complications, or after BPA in patients whose haemodynamic response is unsatisfactory. Prospective studies need to be performed in this setting. In many BPA studies, some or all patients received additional targeted
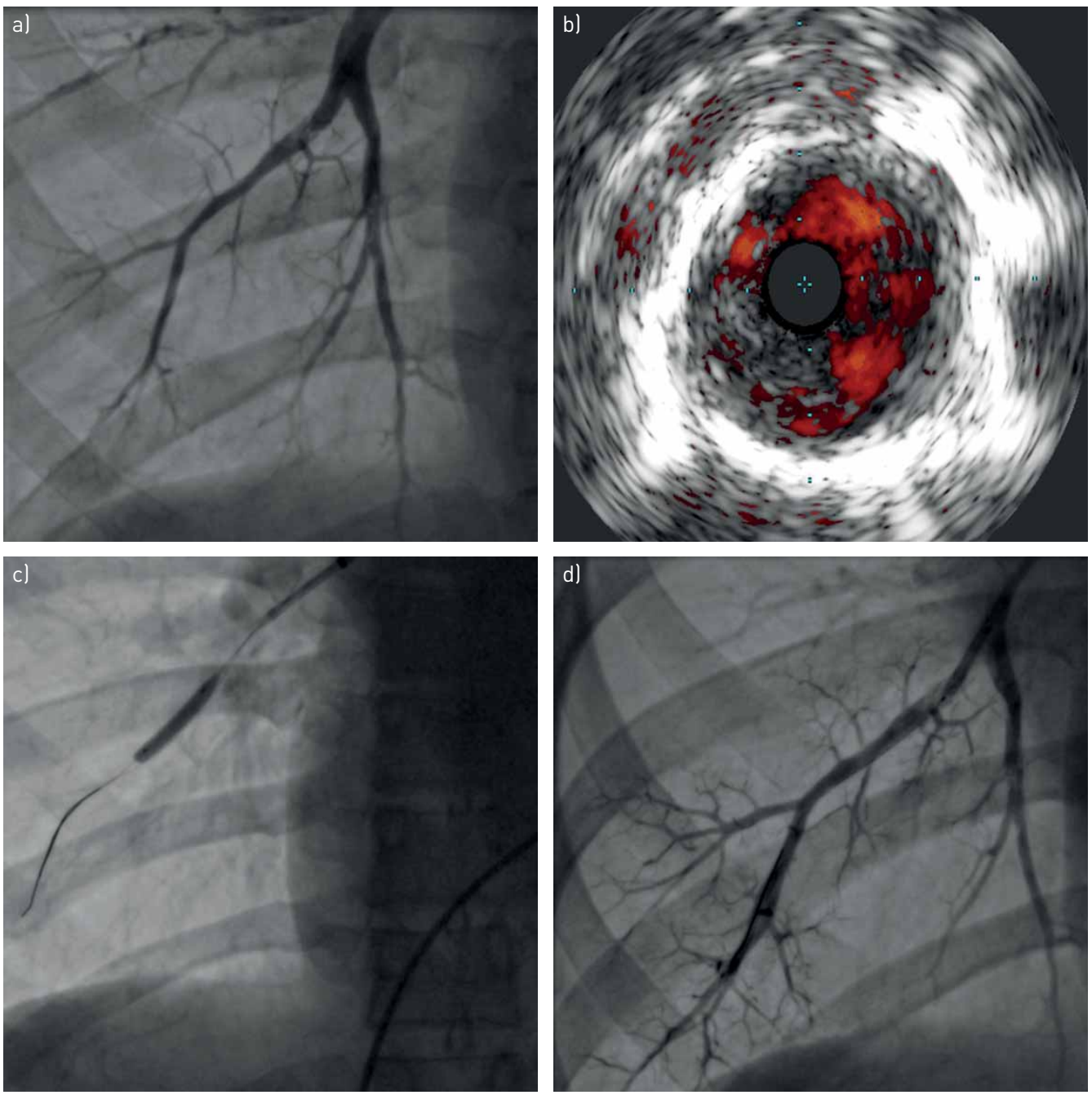

FIGURE 2 Pulmonary arterial imaging before and after percutaneous balloon pulmonary angioplasty (BPA). a) Pre-procedure pulmonary angiogram demonstrating an intra-arterial fibrous "web" lesion; b) the corresponding intravascular ultrasound image showing the intravascular filling defect; $c$ ) the BPA balloon in place; d) pulmonary angiogram after the BPA procedure, showing the patent arterial lumen. 
medical therapy (see table 1) to stabilise the patient or improve haemodynamics before the procedure, and this therapy was generally continued afterwards. However, medical therapy in conjunction with BPA has not been systematically evaluated, and most studies were performed before the advent of riociguat. Successful hybrid therapy with BPA and riociguat has been described in a case report [53]. However, currently no robust data exist on the benefits of treatment with riociguat before and after BPA.

\section{Imaging for BPA}

Accurate pulmonary artery branch intubation and alignment of the guiding catheter to the lesion of interest are essential for BPA; therefore, imaging techniques are critical. Selective pulmonary angiography is used in the anterior-posterior and lateral projections, to reveal stenotic lesions, webs ("slits"), pouches, arterial wall irregularities and complete vascular obstruction, as well as bronchial collaterals. Three-dimensional/rotational angiography of the target vessels may be helpful for diagnosis and procedure guidance $[54,55]$, but bi-plane or single-plane conventional angiography is usually sufficient. Iodinated contrast media are generally used, usually by gentle hand-injection, and using a 1:3 saline dilution. Gadolinium compounds can be considered in patients with iodine allergy.

Digital-subtraction pulmonary angiography is the most common imaging method used to examine the pulmonary vasculature and to determine patient operability [56]. Figure 3 shows selective angiograms and digital-subtraction angiograms from a 76-year-old female with CTEPH manifesting at the level of segmental and subsegmental branching.
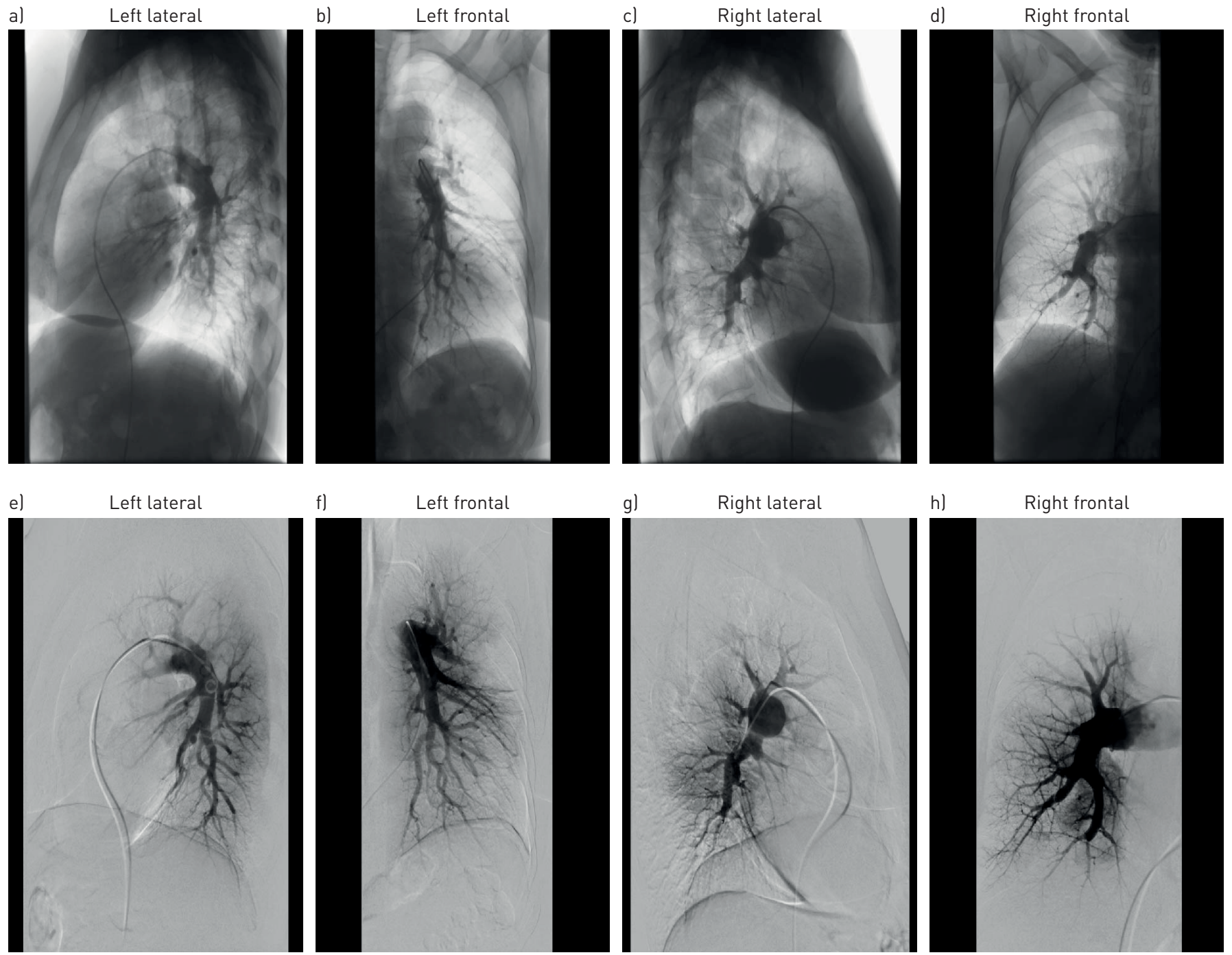

FIGURE 3 a-d) Selective angiograms and e-h) digital-subtraction angiograms of the right and left pulmonary arteries in a 76 -year-old female with chronic thromboembolic pulmonary hypertension manifestation at the level of segmental and subsegmental branching. e-h) Image acquisition in the digital-subtraction angiography technique in frontal or lateral $190^{\circ}$ left anterior oblique) projection using intra-arterial contrast injection (iomeprol $300 \mathrm{mg}$ iodine $\cdot \mathrm{mL}^{-1}$, flow rate $12 \mathrm{~mL} \cdot \mathrm{s}^{-1}$, volume per injection $35 \mathrm{~mL}$, frame rate $7.5 \cdot \mathrm{s}^{-1}$ ). 
Several other imaging techniques may also play a role in patient work-up. Cone-beam computed tomography (CBCT) is important for localisation of relevant intra-arterial lesions and the assessment of pulmonary artery diameter. A recent study by FuKUDA et al. [57] comparing CBCT with selective angiography during BPA has shown that $\mathrm{CBCT}$ can be used to select target lesions in segmental and subsegmental pulmonary artery branches, and gives clearer images of webs and bands than conventional computed tomography angiography. They identified the following lesion types. Type la: webs; type 1b: webs with severe narrowing of the subsegmental artery; type 2: web and slits; type 3: slits; and type 4: pouch defect with incomplete obstruction of subsegmental branches or complete occlusion. $>90 \%$ of lesions diagnosed by CBCT were consistent with the findings on selective angiography during BPA [57].

Contrast-enhanced, C-arm computed tomography (CACT) of the pulmonary arteries is feasible and provides additional information to digital-subtraction angiography, improving the work-up of patients before surgical or interventional treatment $[54,58]$. CACT is accurate for procedure guidance in BPA and pre-acquired image fusion can be used to reduce radiation exposure $[54,58]$. Conventional pulmonary angiography [59], optical coherence tomography (OCT) [60], optical frequency domain imaging [61, 62] and magnetic resonance imaging $[59,63]$ may also be useful in some settings. Figure 4 shows conventional pulmonary angiograms and corresponding OCT images from a patient with CTEPH. Experts in BPA do not recommend OCT other than for cases where the diagnosis is unclear, because forceful injection of
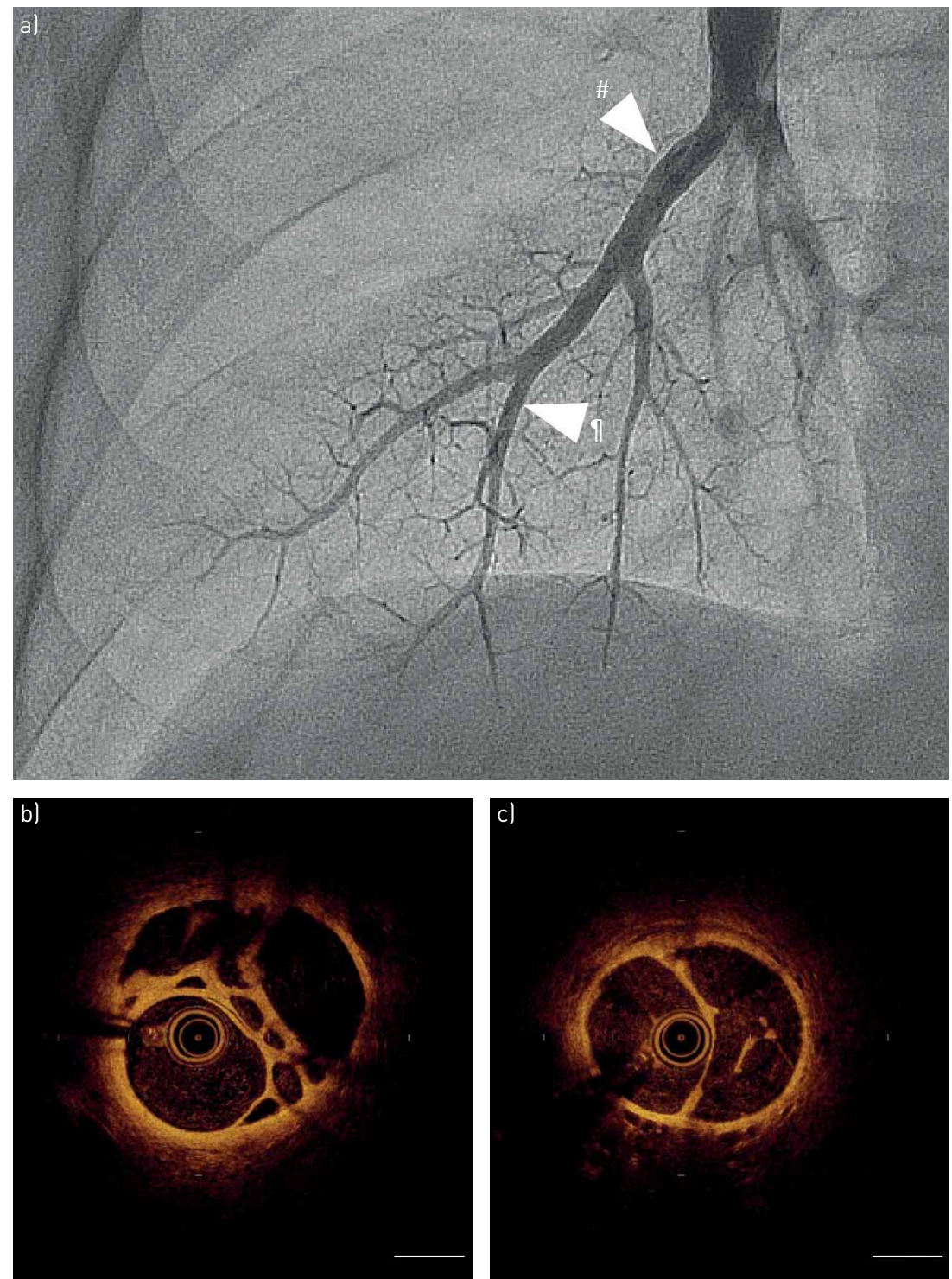

FIGURE 4 a) Conventional pulmonary angiogram, with b) and c) corresponding optical coherence tomography images from a patient with chronic thromboembolic pulmonary hypertension, showing the nature of vascular obstructions at two locations. ": location for b); " : location for cl. Scale bars $=1 \mathrm{~mm}$. 
contrast for the sake of OCT may increase perfusion pressure in the peripheral pulmonary vasculature and cause pulmonary injury.

Dual-energy computed tomography has been used to demonstrate an increase in pulmonary blood volume after BPA [29], and electrocardiogram-gated area detector computed tomography has also been used to guide BPA [30]. Imaging techniques are generally complementary and their diagnostic utility may depend on local practice and expertise [56]. Bearing cost in mind, simple radiographic imaging may be sufficient. In other patients, two or more techniques may be needed to evaluate the lesions fully and determine management.

To date, the classification of vascular lesions considered for BPA has been based on the features of specimens removed during PEA. However, organised thrombi are not removed during BPA; therefore, KAWAKAMI et al. [27] attempted to establish a new classification of vascular lesions based on pulmonary angiographic images. They reviewed 500 consecutive BPA procedures (1936 lesions) in 97 patients and investigated outcomes based on lesion distribution and angiographic characteristics. The lesions were classified into five types, as follows. Type A: ring-like stenosis lesion; type B: web lesion; type C: subtotal lesion; type D: total occlusion lesion; and type E: tortuous lesion. The outcome and complication rates were highly dependent on lesion characteristics. The success rate was higher and the complication rate was lower in ring-like stenosis and web lesions. Total occlusion lesions had the lowest success rate. Tortuous lesions were associated with a high complication rate and should be treated only by operators with extensive experience. The authors concluded that the new classification could help to predict outcome and complication rate of BPA and refine strategies for the procedure.

\section{Safety and limitations of BPA}

The principal complications associated with BPA are pulmonary oedema/pulmonary vascular injury, vessel injury/rupture, pulmonary haemorrhage and haemorrhagic pleural effusion.

\section{Acute pulmonary vascular injury/pulmonary artery rupture, pulmonary haemorrhage and RPO} Patients undergoing BPA are at risk of pulmonary artery injury (PAI) and haemorrhage [64] (table 1). Importantly, respiratory failure may follow pulmonary vessel injury as a result of occult bleeding (B.C. Meyer, Dept of Diagnostic and Interventional Radiology, Hannover Medical School, Hannover, Germany; unpublished data). InAmi et al. [64] identified four categories of PAI: wire perforation, high-pressure perfusion injury, pulmonary artery rupture and pulmonary artery dissection. These complications are an immediate result of procedural error and can lead to signs and symptoms such as haemoptysis, coughing or hypoxia within $20 \mathrm{~min}$, although they can be asymptomatic in some cases. Wire perforation is the most common PAI and is usually caused by deep insertion of a guide wire into peripheral small branches, although if managed correctly, wire perforation does not necessarily lead to RPO. Wire perforation can be reduced by stabilising the guiding catheter and avoiding deep insertion of the guide wire in lesions with unclear distality, or by using CBCT imaging to visualise the distality. The risk may also be reduced by avoiding BPA for complete obstructions, which require a heavy-weight-tip wire [30].

RPO was common in early studies of BPA [15], but its incidence appears to be lower in some recent studies (table 1). In contrast to the immediate complications described, RPO develops $24-72 \mathrm{~h}$ after the procedure. Several types of acute vascular injury can lead to this complication. RPO after BPA was initially believed to arise from the same mechanism as that encountered after PEA $[65,66]$ and to be related to reperfusion itself, involving haemodynamic effects of angioplasty with elevation of the perfusion pressure of the dilated territory. It is now believed to involve additional microtrauma caused by the guide wire and/or balloon, vascular dysfunction, oedema and the release of inflammatory cytokines [30]. However, it is clearly established that this risk is all the more important when the patient has severely impacted haemodynamics (mPAP $>40 \mathrm{mmHg}$ and/or PVR $>7$ Wood Units). Underdeveloped bronchial arteries have been identified as a risk factor for RPO [67]. Refinements to reduce RPO risk include intravascular ultrasound to visualise the vessel and determine the appropriate size of the balloon catheter; use of a soft-tipped 6-French guiding catheter and a 2-mm balloon for initial dilatation; use of non-invasive rather than intravascular imaging modalities [30]; and medical therapy to reduce PAP as much as possible before the procedure [43]. The Pulmonary Edema Predictive Scoring Index, based on flow in the target vessel just before and after angioplasty, has been shown to predict the occurrence of RPO [42]. The addition of a pressure wire technique to maintain a distal $\mathrm{mPAP}<35 \mathrm{mmHg}$ during $\mathrm{BPA}$ sessions, and pressure measurements across the target lesion to estimate the effectiveness of balloon dilatation further reduce the incidence of clinically critical RPO and vessel injuries, and achieve the same haemodynamic improvements with fewer target lesions treated and sessions performed [21].

The belief that RPO was due to reperfusion itself caused some centres to limit the target area for one treatment session to two segments on the same side until the mPAP fell below $30 \mathrm{mmHg}$ [43]. In contrast, a later report from a Japanese centre stated that there is no limit to the number of lobes targeted in one 
session [44]. Therefore, it may not be necessary to limit a session to two vessels; however, that centre limits the maximum time of radiographic fluoroscopy in a single session to $60 \mathrm{~min}$ [44]. The targets and areas for treatment should be decided according to the operator's experience and the type and distribution/location of the patient's lesion.

Pulmonary artery dissection can result from deep intubation of the guiding catheter, and pulmonary artery rupture can occur after dilatation using oversized balloon catheters. Angiography or computed tomography may help to locate PAIs [64]. Interventions to manage PAI include balloon sealing by prolonged, low-pressure dilatation; slow infusion of protamine to reverse the effects of heparin; embolisation with bioabsorbable gelatin or metallic coils; and insertion of covered stents [62, 64, 68, 69]. This is the only setting in which stents are currently used in BPA [9].

\section{X-ray exposure}

The use of repeated intraprocedural angiographic imaging to guide the intervention results in increased $\mathrm{X}$-ray exposure for both operators and patients. This exposure increases with the complexity of the procedure, and may be underestimated by clinicians [70]. CBCT-based image guidance can help to reduce the extent of digital-subtraction angiography, for example by finding appropriate working projections or imaging the course of a pulmonary artery. Furthermore, image fusion of a pre-acquired CACT can be used to decrease radiation exposure due to multiple CBCT acquisitions in several BPA sessions [54].

Currently, BPA should not be offered to patients who are eligible for PEA. In patients with recurrent or persistent pulmonary hypertension, residual pulmonary artery webs or residual lesions after PEA, BPA is less well established, as is PEA.

To date, BPA has only been evaluated in small, uncontrolled studies and knowledge of its long-term effects on haemodynamics, functional capacity and survival remains limited, although data from follow-up studies beyond 1 year in some Japanese centres are promising $[21,22,30]$.

\section{Future perspectives for CTEPH management}

There are many unanswered questions regarding the merits of BPA versus PEA, including standardisation of procedures and set-up, the appropriate target population, the role of medication and outcomes over the long term [71]. There is far more experience of and many more publications about PEA, which is the only intervention that offers a potential for cure. However, BPA is much less invasive than PEA, although it is not without risk and should therefore be conducted only in expert centres and in accordance with current guidelines [1]. An expert centre in Japan reported that PEA had greater effects on haemodynamics than BPA, while effects on $6 \mathrm{MWD}$ and BNP levels were similar [22]. Such comparisons should be interpreted with caution in view of the large differences between patient populations and eligibility criteria. A true comparison of BPA with PEA can be obtained only with large, international, multicentre, controlled clinical studies [72]. Although some patients are clearly eligible for PEA and others for BPA, there is some overlap in terms of the anatomical localisation of thrombi and acceptable or unacceptable risk/benefit ratio of PEA. Comparative trials should address these borderline patients. Such studies should be conducted in high-risk patients eligible for PEA under a multidisciplinary team of surgeons, interventional cardiologists and radiologists. They will be challenging because few centres are able to provide equal expertise in surgery and BPA, and thus recruitment may be difficult. The degree of overlap between eligibility for PEA versus BPA depends on the PEA operator's skill as well as on patient characteristics. Such trials should therefore be undertaken only in high-volume expert PEA centres. In coronary heart disease, the SYNTAX trial compared percutaneous coronary intervention (PCI) with Taxus paclitaxel-eluting stents versus coronary artery bypass surgery in patients with three-vessel or left main coronary artery disease [73]. SYNTAX involved stratification of patients by a risk score based on anatomical assessment of the disease. Surgery was better than PCI (in terms of major adverse cardiovascular or cerebrovascular events) in the tertile with highest risk score [73] and in patients with diabetes [74], while equivalence between PCI and coronary artery bypass surgery was observed in the lower risk tertiles.

Patients with significant chronic vascular occlusions but near-normal pulmonary haemodynamics at rest do not meet the formal definition of CTEPH and are described as having chronic thromboembolic pulmonary vascular disease. The UK CTEPH centre published data on PEA in 42 such patients with baseline mPAP $<25 \mathrm{mmHg}$. There was no in-hospital mortality, and patients had significant improvements in functional status and quality of life, although complications occurred in $40 \%$ of patients [75]. Therefore, it may be expected that BPA could be beneficial in this setting, but no data exist on BPA in this group.

The absence of controlled comparative trials hampers comparisons between BPA and targeted medical therapy. The RACE trial (ClinicalTrials.gov identifier NCT02634203) may address this problem. Patients in France with non-operable CTEPH are being randomised to BPA or medical therapy with riociguat and 
will be followed-up for 26 weeks. The primary end-point will be the change in PVR at week 26. In Japan, a randomised trial comparing riociguat with BPA (MR BPA) is ongoing (UMIN Clinical Trials Registry identifier UMIN000019549).

Future developments in BPA can be expected to refine patient selection, imaging and procedures, potentially leading to the use of BPA in patients who are potentially operable, but in whom the perioperative risk is increased [9]. Developments may include the use of ancillary vascular devices such as stents and steerable guides. An objective risk score to identify candidates for BPA should be developed and validated. CTEPH registries will play a vital part in gathering data to identify the best candidates for BPA. In addition, it may be possible to identify easily assessed biomarkers that allow monitoring of treatment outcomes without the need for invasive measurement of haemodynamic parameters. The implications of concomitant conditions, including diabetes, must also be explored. Further developments in BPA should be based on controlled clinical studies in centres with multidisciplinary CTEPH teams, rather than observational data [72].

Another potential development is the combination of BPA and PEA for patients with CTEPH that is proximal on one pulmonary artery territory and distal on the other. A preliminary study in three patients found that this strategy improved pulmonary haemodynamics and functional class [76]. However, at present this strategy remains experimental.

Advances in BPA may demand more refined definitions of CTEPH and pulmonary artery abnormalities. For example, the distribution of intra-arterial lesions, lesion types, number of chronic total occlusions, proximal or distal distribution of lesions and diameter of pulmonary artery branches should be reported. Future management decisions may be refined according to the location of pulmonary artery lesions: treat proximal lesions with PEA; subsegmental lesions with BPA; and very distal lesions with medical therapy [71]. Future CTEPH management may consist of PEA, BPA and targeted medical therapy combined simultaneously or sequentially and matched to the characteristics of the individual patient in acute settings and as they evolve over time. A flexible strategy may offer the potential for substantial improvements in short- and long-term outcomes.

\section{Acknowledgements}

Editorial assistance was provided by Adelphi Communications Ltd (Bollington, UK), supported by Bayer AG (Berlin, Germany).

\section{References}

1 Galiè N, Humbert M, Vachiery JL, et al. 2015 ESC/ERS Guidelines for the diagnosis and treatment of pulmonary hypertension. The Joint Task Force for the Diagnosis and Treatment of Pulmonary Hypertension of the European Society of Cardiology (ESC) and the European Respiratory Society (ERS). Eur Respir J 2015; 46: 903-975.

2 Banks DA, Pretorius GV, Kerr KM, et al. Pulmonary endarterectomy: part I. Pathophysiology, clinical manifestations, and diagnostic evaluation of chronic thromboembolic pulmonary hypertension. Semin Cardiothorac Vasc Anesth 2014; 18: 319-330.

3 Fedullo P, Kerr KM, Kim NH, et al. Chronic thromboembolic pulmonary hypertension. Am J Respir Crit Care Med 2011; 183: 1605-1613.

4 Kim NH. Group 4 pulmonary hypertension. Chronic thromboembolic pulmonary hypertension: epidemiology, pathophysiology, and treatment. Cardiol Clin 2016; 34: 435-441.

5 Lang IM, Dorfmüller P, Vonk Noordegraaf A. The pathobiology of chronic thromboembolic pulmonary hypertension. Ann Am Thorac Soc 2016; 13 Suppl 3: S215-S221.

6 Wagenvoort CA. Pathology of pulmonary thromboembolism. Chest 1995; 107: 10S-17S.

7 Delcroix M, Lang I, Pepke-Zaba J, et al. Long-term outcome of patients with chronic thromboembolic pulmonary hypertension: results from an international prospective registry. Circulation 2016; 133: 859-871.

8 Jenkins D, Mayer E, Screaton N, et al. State-of-the-art chronic thromboembolic pulmonary hypertension diagnosis and management. Eur Respir Rev 2012; 21: 32-39.

9 Kurzyna M, Darocha S, Koteja A, et al. Balloon pulmonary angioplasty for chronic thromboembolic pulmonary hypertension. Postepy Kardiol Interwencyjnej 2015; 11: 1-4.

10 Jenkins D. Pulmonary endarterectomy: the potentially curative treatment for patients with chronic thromboembolic pulmonary hypertension. Eur Respir Rev 2015; 24: 263-271.

11 Jenkins D, Madani M, Fadel E, et al. Pulmonary endarterectomy in the management of chronic thromboembolic pulmonary hypertension. Eur Respir Rev 2017; 26: 160111.

12 Freed DH, Thomson BM, Berman M, et al. Survival after pulmonary thromboendarterectomy: effect of residual pulmonary hypertension. J Thorac Cardiovasc Surg 2011; 141: 383-387.

13 Mayer E, Jenkins D, Lindner J, et al. Surgical management and outcome of patients with chronic thromboembolic pulmonary hypertension: results from an international prospective registry. J Thorac Cardiovasc Surg 2011; 141: 702-710.

14 Ghofrani HA, D’Armini AM, Grimminger F, et al. Riociguat for the treatment of chronic thromboembolic pulmonary hypertension. N Engl J Med 2013; 369: 319-329.

15 Feinstein JA, Goldhaber SZ, Lock JE, et al. Balloon pulmonary angioplasty for treatment of chronic thromboembolic pulmonary hypertension. Circulation 2001; 103: 10-13.

16 Kataoka M, Inami T, Hayashida K, et al. Percutaneous transluminal pulmonary angioplasty for the treatment of chronic thromboembolic pulmonary hypertension. Circ Cardiovasc Interv 2012; 5: 756-762.

17 Sugimura K, Fukumoto Y, Satoh K, et al. Percutaneous transluminal pulmonary angioplasty markedly improves pulmonary hemodynamics and long-term prognosis in patients with chronic thromboembolic pulmonary hypertension. Circ J 2012; 76: 485-488. 
18 Andreassen AK, Ragnarsson A, Gude E, et al. Balloon pulmonary angioplasty in patients with inoperable chronic thromboembolic pulmonary hypertension. Heart 2013; 99: 1415-1420.

19 Fukui S, Ogo T, Morita Y, et al. Right ventricular reverse remodelling after balloon pulmonary angioplasty. Eur Respir J 2014; 43: 1394-1402.

20 Shimura N, Kataoka M, Inami T, et al. Additional percutaneous transluminal pulmonary angioplasty for residual or recurrent pulmonary hypertension after pulmonary endarterectomy. Int J Cardiol 2015; 183: 138-142.

21 Inami T, Kataoka M, Shimura N, et al. Pressure-wire-guided percutaneous transluminal pulmonary angioplasty: a breakthrough in catheter-interventional therapy for chronic thromboembolic pulmonary hypertension. JACC Cardiovasc Interv 2014; 7: 1297-1306.

22 Inami T, Kataoka M, Ando M, et al. A new era of therapeutic strategies for chronic thromboembolic pulmonary hypertension by two different interventional therapies; pulmonary endarterectomy and percutaneous transluminal pulmonary angioplasty. PLoS One 2014; 9: e94587.

23 Yanagisawa R, Kataoka M, Inami T, et al. Safety and efficacy of percutaneous transluminal pulmonary angioplasty in elderly patients. Int J Cardiol 2014; 175: 285-289.

24 Velázquez Martín M, Albarrán González-Trevilla A, Alonso Charterina S, et al. Balloon pulmonary angioplasty for inoperable patients with chronic thromboembolic pulmonary hypertension. Preliminary experience in Spain in a series of 7 patients. Rev Esp Cardiol 2015; 68: 535-537.

25 Roik M, Wretowski D, Łabyk A, et al. Refined balloon pulmonary angioplasty driven by combined assessment of intra-arterial anatomy and physiology - multimodal approach to treated lesions in patients with non-operable distal chronic thromboembolic pulmonary hypertension - technique, safety and efficacy of 50 consecutive angioplasties. Int J Cardiol 2016; 203: 228-235.

26 Aoki T, Sugimura K, Nochioka K, et al. Effects of balloon pulmonary angioplasty on oxygenation in patients with chronic thromboembolic pulmonary hypertension - importance of intrapulmonary shunt. Circ J 2016; 80: 2227-2234.

27 Kawakami T, Ogawa A, Miyaji K, et al. Novel angiographic classification of each vascular lesion in chronic thromboembolic pulmonary hypertension based on selective angiogram and results of balloon pulmonary angioplasty. Circ Cardiovasc Interv 2016; 9: e003318.

28 Kimura M, Kohno T, Kawakami T, et al. Balloon pulmonary angioplasty attenuates ongoing myocardial damage in patients with chronic thromboembolic pulmonary hypertension. Int J Cardiol 2016; 207: 387-389.

29 Koike H, Sueyoshi E, Sakamoto I, et al. Quantification of lung perfusion blood volume (lung PBV) by dual-energy CT in patients with chronic thromboembolic pulmonary hypertension (CTEPH) before and after balloon pulmonary angioplasty (BPA): preliminary results. Eur J Radiol 2016; 85: 1607-1612.

30 Ogo T, Fukuda T, Tsuji A, et al. Efficacy and safety of balloon pulmonary angioplasty for chronic thromboembolic pulmonary hypertension guided by cone-beam computed tomography and electrocardiogram-gated area detector computed tomography. Eur J Radiol 2017; 89: 270-276.

31 Tsugu T, Murata M, Kawakami T, et al. Changes in right ventricular dysfunction after balloon pulmonary angioplasty in patients with chronic thromboembolic pulmonary hypertension. Am J Cardiol 2016; 118: 1081-1087.

32 Yamasaki Y, Nagao M, Abe K, et al. Balloon pulmonary angioplasty improves interventricular dyssynchrony in patients with inoperable chronic thromboembolic pulmonary hypertension: a cardiac MR imaging study. Int $J$ Cardiovasc Imaging 2017; 33: 229-239.

33 Tsuji A, Ogo T, Ueda J, et al. Predictors of residual pulmonary hypertension after balloon pulmonary angioplasty in patients with chronic thromboembolic pulmonary hypertension. Int J Cardiol 2017; 226: 118-120.

34 Kopeć G, Stępniewski J, Waligóra M, et al. Staged treatment of central and peripheral lesions in chronic thromboembolic pulmonary hypertension. Pol Arch Med Wewn 2016; 126: 97-99.

35 Taniguchi Y, Miyagawa K, Nakayama K, et al. Balloon pulmonary angioplasty: an additional treatment option to improve the prognosis of patients with chronic thromboembolic pulmonary hypertension. EuroIntervention 2014; 10: $518-525$

36 Broch K, Murbraech K, Ragnarsson A, et al. Echocardiographic evidence of right ventricular functional improvement after balloon pulmonary angioplasty in chronic thromboembolic pulmonary hypertension. $J$ Heart Lung Transplant 2016; 35: 80-86.

37 Sato $\mathrm{H}$, Ota $\mathrm{H}$, Sugimura $\mathrm{K}$, et al. Balloon pulmonary angioplasty improves biventricular functions and pulmonary flow in chronic thromboembolic pulmonary hypertension. Circ J 2016; 80: 1470-1477.

38 Tsugu T, Murata M, Kawakami T, et al. Significance of echocardiographic assessment for right ventricular function after balloon pulmonary angioplasty in patients with chronic thromboembolic induced pulmonary hypertension. Am J Cardiol 2015; 115: 256-261.

39 Takei M, Kataoka M, Kawakami T, et al. Respiratory function and oxygenation after balloon pulmonary angioplasty. Int J Cardiol 2016; 212: 190-191.

40 Kim NH, Delcroix M, Jenkins DP, et al. Chronic thromboembolic pulmonary hypertension. J Am Coll Cardiol 2013; 62: D92-D99.

41 Collaud S, Brenot P, Mercier O, et al. Rescue balloon pulmonary angioplasty for early failure of pulmonary endarterectomy: the earlier the better? Int J Cardiol 2016; 222: 39-40.

42 Inami T, Kataoka M, Shimura N, et al. Pulmonary edema predictive scoring index (PEPSI), a new index to predict risk of reperfusion pulmonary edema and improvement of hemodynamics in percutaneous transluminal pulmonary angioplasty. JACC Cardiovasc Interv 2013; 6: 725-736.

43 Mizoguchi H, Ogawa A, Munemasa M, et al. Refined balloon pulmonary angioplasty for inoperable patients with chronic thromboembolic pulmonary hypertension. Circ Cardiovasc Interv 2012; 5: 748-755.

44 Ogawa A, Matsubara H. Balloon pulmonary angioplasty: a treatment option for inoperable patients with chronic thromboembolic pulmonary hypertension. Front Cardiovasc Med 2015; 2: 4.

45 Auger WR, Fedullo PF, Moser KM, et al. Chronic major-vessel thromboembolic pulmonary artery obstruction: appearance at angiography. Radiology 1992; 182: 393-398.

46 Kawakami T, Kataoka M, Arai T, et al. Retrograde approach in balloon pulmonary angioplasty: useful novel strategy for chronic total occlusion lesions in pulmonary arteries. JACC Cardiovasc Interv 2016; 9: e19-e20.

47 Geschka S, Kretschmer A, Sharkovska Y, et al. Soluble guanylate cyclase stimulation prevents fibrotic tissue remodeling and improves survival in salt-sensitive Dahl rats. PLoS One 2011; 6: e21853. 
48 Ghofrani HA, Humbert M, Langleben D, et al. Riociguat: mode of action and clinical development in pulmonary hypertension. Chest 2017; 151: 468-480.

49 Lang M, Kojonazarov B, Tian X, et al. The soluble guanylate cyclase stimulator riociguat ameliorates pulmonary hypertension induced by hypoxia and SU5416 in rats. PLoS One 2012; 7: e43433.

50 Schermuly RT, Stasch JP, Pullamsetti SS, et al. Expression and function of soluble guanylate cyclase in pulmonary arterial hypertension. Eur Respir J 2008; 32: 881-891.

51 Sharkovska Y, Kalk P, Lawrenz B, et al. Nitric oxide-independent stimulation of soluble guanylate cyclase reduces organ damage in experimental low-renin and high-renin models. J Hypertens 2010; 28: 1666-1675.

52 Stasch JP, Evgenov OV. Soluble guanylate cyclase stimulators in pulmonary hypertension. Handb Exp Pharmacol 2013; 218: 279-313.

53 Tsugu T, Murata M, Kawakami T, et al. Amelioration of right ventricular function after hybrid therapy with riociguat and balloon pulmonary angioplasty in patients with chronic thromboembolic pulmonary hypertension. Int J Cardiol 2016; 221: 227-229.

54 Hinrichs JB, Renne J, Hoeper MM, et al. Balloon pulmonary angioplasty: applicability of C-Arm CT for procedure guidance. Eur Radiol 2016; 26: 4064-4071.

55 Yanagisawa $R$, Kataoka $M$, Inami $T$, et al. Efficacy of 360-degree three-dimensional rotational pulmonary angiography to guide percutaneous transluminal pulmonary angioplasty. EuroIntervention 2014; 9: 1483.

56 Lang IM, Plank C, Sadushi-Kolici R, et al. Imaging in pulmonary hypertension. JACC Cardiovasc Imaging 2010; 3: $1287-1295$.

57 Fukuda T, Ogo T, Nakanishi N, et al. Evaluation of organized thrombus in distal pulmonary arteries in patients with chronic thromboembolic pulmonary hypertension using cone-beam computed tomography. Jpn J Radiol 2016; 34: 423-431.

58 Hinrichs JB, Marquardt S, von Falck C, et al. Comparison of C-arm computed tomography and digital subtraction angiography in patients with chronic thromboembolic pulmonary hypertension. Cardiovasc Intervent Radiol 2016; 39: 53-63.

59 D'Armini AM. Diagnostic advances and opportunities in chronic thromboembolic pulmonary hypertension. Eur Respir Rev 2015; 24: 253-262.

60 Inohara T, Kawakami T, Kataoka M, et al. Lesion morphological classification by OCT to predict therapeutic efficacy after balloon pulmonary angioplasty in CTEPH. Int J Cardiol 2015; 197: 23-25.

61 Ikeda N, Kubota S, Okazaki T, et al. Comparison of intravascular optical frequency domain imaging versus intravascular ultrasound during balloon pulmonary angioplasty in patients with chronic thromboembolic pulmonary hypertension. Catheter Cardiovasc Interv 2016; 87: E268-E274.

62 Horimoto $\mathrm{K}$, Abe $\mathrm{K}$, Ohtani $\mathrm{K}$, et al. Optical frequency domain imaging of covered stent-graft for pulmonary artery pseudoaneurysm after balloon pulmonary angioplasty. JACC Cardiovasc Interv 2016; 9: 2255-2256.

63 Giannouli E, Maycher B. Imaging techniques in chronic thromboembolic pulmonary hypertension. Curr Opin Pulm Med 2013; 19: 562-574.

64 Inami $\mathrm{T}$, Kataoka $\mathrm{M}$, Shimura $\mathrm{N}$, et al. Incidence, avoidance, and management of pulmonary artery injuries in percutaneous transluminal pulmonary angioplasty. Int J Cardiol 2015; 201: 35-37.

65 Adams A, Fedullo PF. Postoperative management of the patient undergoing pulmonary endarterectomy. Semin Thorac Cardiovasc Surg 2006; 18: 250-256.

66 Thistlethwaite PA, Kaneko K, Madani MM, et al. Technique and outcomes of pulmonary endarterectomy surgery. Ann Thorac Cardiovasc Surg 2008; 14: 274-282.

67 Takei M, Kataoka M, Kawakami T, et al. Under-developed bronchial arteries as a risk factor for complications in balloon pulmonary angioplasty. Int J Cardiol 2016; 203: 1016-1017.

68 Ejiri K, Ogawa A, Matsubara H. Bail-out technique for pulmonary artery rupture with a covered stent in balloon pulmonary angioplasty for chronic thromboembolic pulmonary hypertension. JACC Cardiovasc Interv 2015; 8: $752-753$

69 Hosokawa $\mathrm{K}$, Abe $\mathrm{K}$, Oi K, et al. Balloon pulmonary angioplasty-related complications and therapeutic strategy in patients with chronic thromboembolic pulmonary hypertension. Int J Cardiol 2015; 197: 224-226.

70 Smith IR, Rivers JT. Measures of radiation exposure in cardiac imaging and the impact of case complexity. Heart Lung Circ 2008; 17: 224-231.

71 Lang IM, Madani M. Update on chronic thromboembolic pulmonary hypertension. Circulation 2014; 130: 508-518.

72 Vachiéry JL, Gaine S. Challenges in the diagnosis and treatment of pulmonary arterial hypertension. Eur Respir Rev 2012; 21: 313-320.

73 Serruys PW, Morice MC, Kappetein AP, et al. Percutaneous coronary intervention versus coronary-artery bypass grafting for severe coronary artery disease. N Engl J Med 2009; 360: 961-972.

74 Kappetein AP, Head SJ, Morice MC, et al. Treatment of complex coronary artery disease in patients with diabetes: 5 -year results comparing outcomes of bypass surgery and percutaneous coronary intervention in the SYNTAX trial. Eur J Cardiothorac Surg 2013; 43: 1006-1013.

75 Taboada D, Pepke-Zaba J, Jenkins DP, et al. Outcome of pulmonary endarterectomy in symptomatic chronic thromboembolic disease. Eur Respir J 2014; 44: 1635-1645.

76 Wiedenroth CB, Liebetrau C, Breithecker A, et al. Combined pulmonary endarterectomy and balloon pulmonary angioplasty in patients with chronic thromboembolic pulmonary hypertension. J Heart Lung Transplant 2016; 35: 591-596. 